\title{
Engineer Leonard SzUtKowski - Manager of the State Quarries in JanOWa Dolina in Volhynia
}

Słowa kluczowe: Janowa Dolina, Wołyń, Szutkowski, kamieniołom, Kresy Wschodnie

Keyw ord s: Janowa Dolina, Volhynia, Szutkowski, quarry, Eastern Borderlands

\begin{abstract}
An in-depth analysis of Leonard Szutkowski's biographical documents shows that he was an outstanding patriot who devoted most of his professional life to the economic development of Poland. He was born into a landowning family, did his military service in the tsarist army, and escaped from Bolshevik captivity. In independent Poland, he did not continue his military career but worked in the state administration as an engineer responsible for road works. He continued his engineer's work during the Polish-Bolshevik war. Later, he managed the quarries in Janowa Dolina in Volhynia and made them a model enterprise on a European scale. He paid the highest price for his attitude to life. Until now many aspects of his activity have been unknown. Only the archive search in Ukraine made it possible to gain knowledge about views and details of his socio-political activity. The research employed a biographical method based on the analysis of personal documents. Scientific studies on particular
\end{abstract}


topics related to Leonard Szutkowski were also taken into account. The research was supplemented by an analysis of press materials from the period in question.

O nly several studies include biographical materials concerning Leonard Szutkowski. Recently, he was mentioned by Agnieszka Rybak and Anna Smółka in their reporter's book Wieża Eiffla nad Pinq. Kresowe marzenia II RP ${ }^{1}$. Most memoirs and studies focus on the quarries in Janowa Dolina ${ }^{2}$, which he managed, and the massacre that took place there in 1943. In 2016, during one of his interviews, prof. Stanisław S. Nicieja spoke about the historical awareness of Poles: "we know that many people were murdered there, but not that there was an impressive quarry..."

Leonard Szutkowski was born on 16 June 1887 in the family estate of Khmelyshche (Chmieliszcze) ${ }^{4}$ near Kobryn in Polesia (Polish: Polesie) (Belarus at present). He came from a Polish Catholic family. He was a son of Piotr ${ }^{5}$

1 A. Rybak, A. Smółka, Wieża Eiffla nad Pinq. Kresowe marzenia II RP, Wołowiec 2019, pp. 143-178.

2 B. Soboń, Wotyński życiorys: wspomnienia i refleksje (wokót kopali bazaltu w Janowej Dolinie pow. Kostopol), Warszawa 1999; W. Mędrzecki, Kresowy kalejdoskop. Wędrówki przez ziemie wschodnie Drugiej Rzeczypospolitej 1918-1939, Kraków 2018, p. 264.

${ }^{3}$ D. Chajewski, Stanisław Nicieja: jestem jak płetwonurek szukajacy Atlantydy, https:// plus.gazetalubuska.pl/stanislaw-nicieja-jestem-jak-pletwonurek-szukajacy-atlantydy/ ar/c1-14661737 (5.05.2020).

${ }^{4}$ The Szutkowski family's property is mentioned in: B. Chlebowski (ed.), Stownik Geograficzny Królestwa Polskiego i innych krajów stowiańskich, vol. XV part 1, Warszawa 1900, p. 307. Vide: The Archive of the Institute of National Remembrance in Katowice [hereinafter: AIPN Ka], 555/4621, Copy of the baptismal certificate of Leonard Szutkowski, sheet 2.

${ }^{5}$ Piotr Szutkowski (1854-1918), a landowner, son of Wincenty (born in 1829) and Wiktoria, née Redko (born in 1828), owner of the Khmelyshche estate near Kobryn in Polesia. He had 6 children with his first wife Maria, née Juszkiewicz (born 1856). After her death, he married Kamila, née Zapolska (born 1858), and also had 6 children with her. Piotr's heirs were mentioned in the announcement of the Polesia Regional Land Office concerning land consolidation and granting newly established colonies. His sons were: Antoni, Franciszek, Henryk, Lucjan, Leonard, Wincenty, Julian, and Piotr. Daughters: Felicja, Anna, Albertyna, and Maria. Vide: "Poleski Dziennik Wojewódzki" 1933, no. 18, p. 290; Piotr Szutkowski, https://www.myheritage.pl (5.052020). 
and Kamila from the Zapolski family ${ }^{6}$, and had numerous siblings. Among his brothers were ${ }^{7}$ : Antoni, Franciszek, Henryk, Lucjan ${ }^{8}$, Wincent ${ }^{9}$, Julian $^{10}$,

${ }^{6}$ Kamila Szutkowska, née Zapolska (1858-1905), wife of landowner Piotr Szutkowski, vide: Kamilla Szutkowska (née Zapolska), https://www.myheritage.pl (5.05.2020).

${ }^{7}$ Apart from them, also Aleksander Szutkowski (died on 23 IV 1943) is mentioned in the literature. He died during a Ukrainian Insurgent Army's attack on Janowa Dolina. W. Siemaszko, E. Siemaszko, Ludobójstwo dokonane przez nacjonalistów ukrainskich na ludności polskiej Wołynia 1939-1945, vol. I, Warszawa 2000, p. 235. However, I have not managed to confirm the authenticity of this figure and his possible kinship with Leonard Szutkowski.

${ }^{8}$ Lucjan Szutkowski (1883-1933), son of Piotr and Maria, née Juszkiewicz. He remained in his father's estate: T. Epsztain, S. Górzyński (eds.), Spis ziemian Rzeczypospolitej Polskiej w roku 1930: województwo poleskie, województwo wotyńskie, Warszawa 1996, p. 32.

${ }^{9}$ Wincenty Szutkowski (1889-25 XI 1966) - in 1911-1918, he served in the Russian 88th Infantry Regiment. In 1918-1924, he was a clerk in Kobryn, and then until 1939, he was a clerk in the Voivodeship Office in Brest. On 23 XI 1944, he was arrested by the NKVD in Biała Podlaska. vide: Central Military Archives in Warsaw [hereinafter: CAW], Collection of the Military Archival Commission, Szutkowski Wincenty, ref. no. VIII.802.1300.26744; Nekrologi warszawskie, http://www.nekrologi-baza.pl/zmarly/286574 (2.05.2020); Wincenty Szutkowski, https://www.myheritage.pl (5.05.2020).

${ }^{10}$ Julian Szutkowski (20 VII 1894-1940) - major, in 2007 posthumously promoted to the rank of lieutenant colonel. He studied at the Faculty of Chemistry of the Warsaw University of Technology. Since 1916, he served in the Russian army, and in 1917 he joined the Polish I Corps under the command of General Józef Dowbór-Muśnicki. After one of the battles, he found himself captive of the Bolsheviks and then the Germans. In December 1918, after he was released by the Germans, he joined the Polish Army and became a student of the Artillery Training Centre. He took part in the Polish-Soviet War, commanded the ammunition troop of the 1st Legions Infantry Division. After the end of the war, he served, among others, in the 3rd heavy artillery regiment, as a manager in the Regional Armament Facility No. 10 in Przemyśl, in the Gas Equipment Repair Workshop, and the Armament School in Warsaw. During the war he was assigned to the 29th Infantry Division. Murdered by the NKVD in Kharkiv in 1940. Buried in the Cemetery to the Victims of Totalitarianism in Piatykhatky. After: CAW, Collection of Personal Records and Decorations [hereinafter: KAPiO], Szutkowski Julian, Committee of the Cross and the Medal of Independence 15-4377, Application of 27 XII 1937; ibidem, Szutkowski Julian, AP 16477, Qualification card for the Verification Committee; ibidem, Qualification card; Biogramy Ofiar Zbrodni Katyńskiej, http://ksiegicmentarne. muzeumkatynskie.pl/wpis/7623 (21.05.2020); Julian Szutkowski (ID: katyn.736), [in:] Genealogia potomków Sejmu Wielkiego, M. J. Minakowski (ed.), http://www.sejm-wielki. 
Piotr $^{11}$, and among his sisters: Felicja, Anna, Albertyna ${ }^{12}$ and Maria ${ }^{13}$. Initially, he learned from his mother, who conducted secret teaching activities for Polish children in the area. In 1901, he started learning in the municipal school in Kobryn. After graduation, he enrolled in the Chemical and Technical School in Vilnius. As a result of participation in school strikes in 1905-1906, demonstrations, and confrontations with Cossacks, he was expelled from school ${ }^{14}$. He moved to St. Petersburg to study. There, he attended general education programmes of Alexander Sergeyevich Chernyayev, where many famous professors delivered lectures (these courses were later attended by, among others, Yanka Kupala, a well-known Belarusian writer ${ }^{15}$ ). Szutkowski completed the programmes in 1908. Then, he passed examinations in St. Petersburg and received a certificate of 6 classes of the Cadet Corps. As a volunteer, he joined the 2nd Field Artillery Brigade in Biała Podlaska. In January the following year, he was appointed a junior bombardier, and in April, reassigned to Warsaw. There, as an extern at the Cadet Corps, he passed his Matura exam in 1909. He wrote in the language skills section: in speech - Polish and Russian, and writing French and German. After the Matura exam, he returned to the brigade and became a junior non-commissioned officer in May. In July, he was reassigned to the Warsaw District Command, where he passed the reserve warrant officer's exam. He returned to his unit and received a leave of absence in August, enabling him to take exams at the Warsaw University of Technology. In September,

pl/b/katyn.736 (21.05.2020); W. Kozłowski, Artyleria polskich formacji wojskowych podczas I wojny światowej, Łódź 1993, p. 256.

11 Piotr Szutkowski (1900-1984), son of Piotr and Kamila, née Zapolska. In 1935, married Władysława Natkowska (born on 2 XII 1910). Vide: Piotr Szutkowski, https:// www.myheritage.pl (5.05.2020).

12 Zofia Albertyna Farbiszewska, née Szutkowska (1893-1976), wife of Walery Farbiszewski, section secretary in the Ministry of Supply in Warsaw. Vide: Zofia Albertyna Farbiszewska (née Szutkowska), 1893-1976, https://www.myheritage.pl (5.05.2020); The Archives of Modern Records in Warsaw, Ministry of Supply in Warsaw, ref. no. 2/19/0/14.2/2689, Farbiszewski Walery [section secretary - personal files].

13 Maria Szutkowska (1881-1976), vide: Miss Maria (née Szutkowska), 1881-1976, https://www.myheritage.pl (5.05.2020).

14 CAW, KAPiO, Szutkowski Leonard, 21 VI 1938, Rejected, CV of Leonard Szutkowski.

15 Купала Янка, [in:] Электронная Энцыкляпэдыя, 2003-2020, http://slounik. org/120792.html (5.05.2020); L. Sawik, Kosmos Białorusa, http://bkit.lt/kita.pl.html (5.05.2020). 
he was dismissed from the army, and in November, promoted to the reserve warrant officer rank. Then, he left the military. Between 1909 and 1914, he studied at the Faculty of Mining of the Warsaw University of Technology. He was a member of the Mutual Aid Society of Polish Students. In 1911, he took part in a students' strike and, two years later, in a demonstration in front of the German consulate, during which he protested against Poles' persecution in Germany. He was a trainee at the "Paryż" and "Flora" mines in Dąbrowa Górnicza and conducted geological surveys in the vicinity of Olkusz, Kielce, and Działoszyn ${ }^{16}$.

Leonard Szutkowski. Photo from the collection of the Katyn Museum

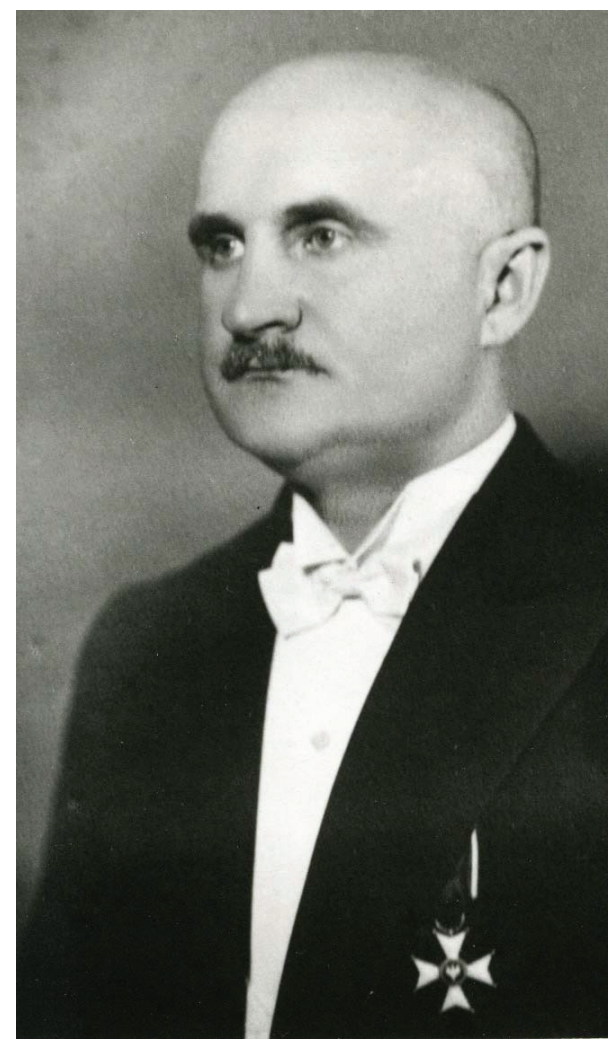

16 Derżawnyj Archiw Wołynśkoji Obłasti in Lutsk (Ukraine) [abbreviated as: DAWO], fond 46, description 7, case 2769, Official declaration (after 14 II 1920), sheet 3; ibidem, Summary of information about the candidate dated 30 III 1920, sheet I/6v; ibidem, Application of L. Szutkowski to the technical inspector of Brest Region (Okręg Brzeski) from January 1920, sheet II/2; ibidem, Curriculum vitae of L. Szutkowski of 3 IV 1920, sheet II/ 3; ibidem, A brief CV of L. Szutkowski of 3 X 1920, sheet II/4; ibidem, CV of 1 II 1921, sheet II/5. Some documents include the date of birth, determined in accordance with the Gregorian calendar, but others, like the diploma in engineering from the Academy of Mining in Cracow - 16 VI 1887: ibidem, Diploma of L. Szutkowski confirming that he was awarded the degree of mining engineer, sheet II/32; ibidem, Certificate of 20 II 1935 on the military service of eng. L. Szutkowski, reserve lieutenant, for the purpose of receiving pension, sheet II/35; CAW, KAPiO, Leonard..., CV...; Ogłoszenie poleskiego okręgowego urzędu ziemskiego o scaleniu gruntów i przyznaniu nowoutworzonych kolonji, "Poleski Dziennik Wojewódzki” 1933, no. 18, p. 290. 


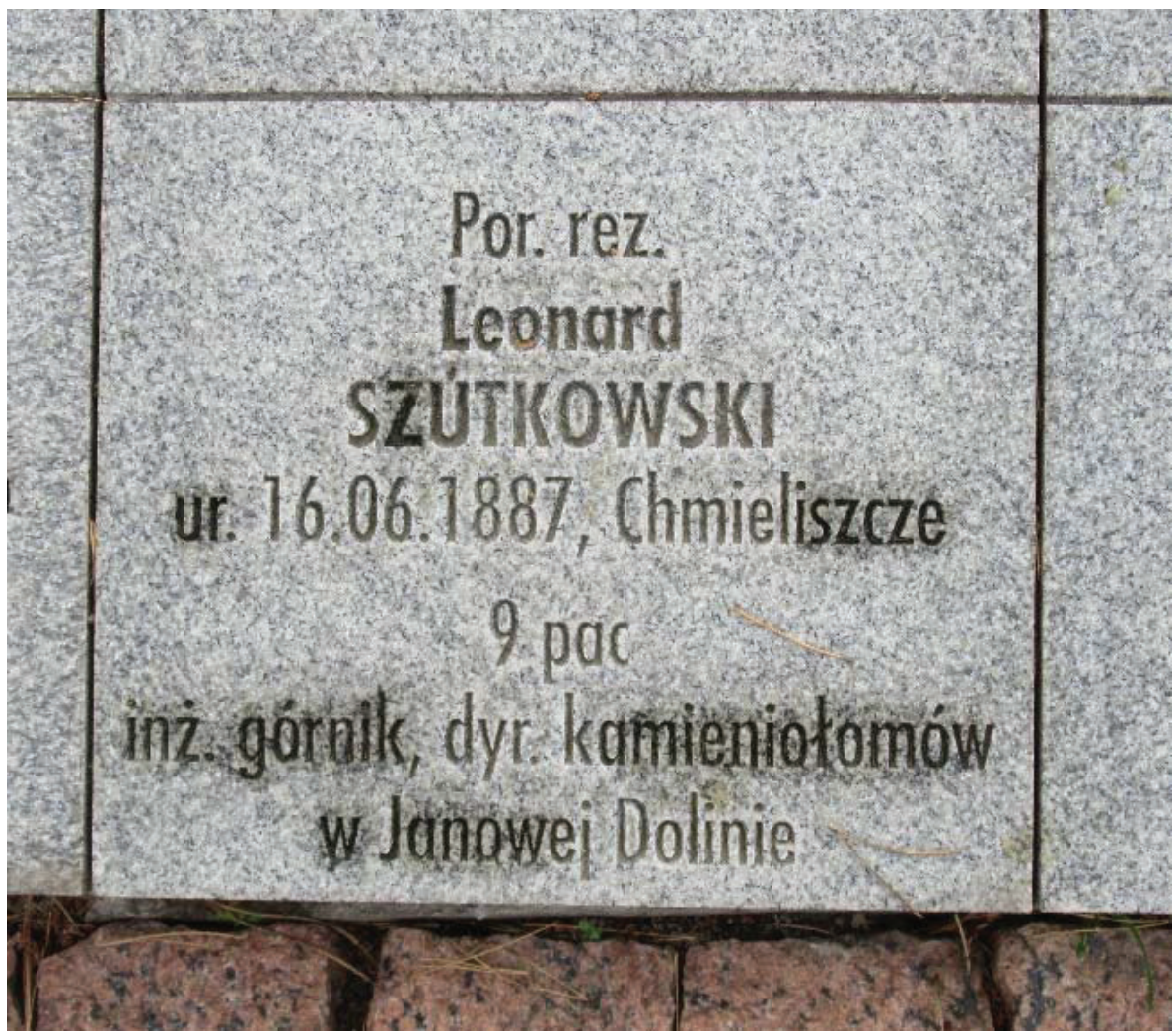

Leonard Szutkowski's tombstone in Bykivnia (photo by Jarosław Durka

He started a family. On 25 June 1912, he married Sabina Szerszenowicz (1892-1971), five years younger than him ${ }^{17}$. They had three children: Edmund

17 DAWO, fond 46, description 7, case 2769, Copy of the marriage certificate of $25 \mathrm{VI}$ 1921, sheet II/8; AIPN Ka, 555/4621, Letter of 21 XI 1950 from Sabina Szutkowska to the Magistrate Court in Zabrze, sheet 1; CAW, KAPiO, Szutkowski Leonard, AP 16476, Record sheet. 
(born on $26 \mathrm{VI} 1913^{18}$, died on 4 VI 1936) ${ }^{19}$, Leonard (born $\left.13 \mathrm{X} 1916^{20}\right)^{21}$, and

18 Ibidem. According to the birth certificate, the date is: $13 \mathrm{VI}$, according to Julian calendar: ibidem, Copy of the birth certificate of 11 IX 1922, sheet II/9.

19 Edmund Szutkowski (25 VI 1913 - 4 VI 1936) - in 1935, he became a glider pilot in Sokola Góra in Volhynia. On 2 January 1936, he obtained category C - official. In 1936, after graduating from secondary school, he enrolled in the Faculty of Mechanical Engineering of the Warsaw University of Technology and wanted to become an aircraft constructor. He was a member of the Board of the Aviation Section of the University of Technology. Under the direction of Gustaw Mokrzycki, he designed a tailless sport airplane "SSS" together with Jan Tadeusz Staszek and Leszek Szwar in the Airframe Design Department. He conducted theoretical courses for young aviation adepts in the Warsaw Branch of Airborne and Antigas Defense League (LOPP). He beat the records of Volhynia in glider flights (flight duration and flight altitude). He was to represent the Warsaw Branch of LOPP at the nationwide competition in Ustianowa. However, he had to pass a course for aerotow flights behind a plane. He started it at the airport in Mokotów. He died on the fourth flight during the course. His glider fell on a house at Rakowiecka street. During the competition in Ustianowa, the Aviation Section of the Mechanics Club of the Students of Warsaw University of Technology founded an award named after him (it was granted to pilot Henryk Milicer). Vide: Ś.P. Edmund Szutkowski, "Skrzydlata Polska" 1936, no. 7, p. 206; Rozkwit Wołyńskiej Szkoły Szybowcowej na Sokolej Górze, "Skrzydlata Polska" 1936, no. 7, p. 188; Zginął w katastrofie lotniczej, "Dziennik Bydgoski” 9 IX 1936, no. 133, p. 4; S.I., VI Krajowe Zawody Szybowcowe, "Lot i Obrona Przeciwlotniczo-Gazowa Polski” 1936, no. 8-9, p. 34; Katastrofa szybowca, "Dziennik Poznański”, 5 VI 1936, no. 257, p. 1; Z. Mikulski, Wspaniały rozwój Szkoły Szybowcowej na Sokolej Górze koło Krzemieńca, "Życie Krzemienieckie" 1934, no. 4, http://nawolyniu.pl/artykuly/sokolagora.pdf (5.05.2020); A. Glass, Jan Tadeusz Staszek, https://www.ipsb.nina.gov.pl/a/biografia/jan-tadeusz-staszek (5.05.2020); W. Mędrzecki, Inteligencja polska na Wołyniu w okresie międzywojennym, Warszawa 2005, p. 322.

20 According to the copy of the birth certificate, the date is: 30 September, according to Julian calendar: ibidem. Copy of the birth certificate of 6 II 1918, sheet II/10.

${ }^{21}$ Leonard Szutkowski (30 IX 1916 - 29 III 2002 in the United States) - a platoon officer cadet, Master of Law. On 13 IV 1940, he was arrested in Janowa Dolina. He was probably transported to Posiołek Limanówka in Kostanay Oblast where he worked on a farm as an exile. On 30 VIII 1941, he was granted amnesty, but trying to leave the place of deportation, he encountered numerous obstacles from the administrative authorities and the Soviet Military Commissariat in Kostanay. He arrived in Buzuluk, where the Polish Army in the East was being formed, only on 25 I 1942. He was a lieutenant of the 3rd Carpathian Light Artillery Regiment in the Polish II Corps. He was awarded the Cross of Valor for participation in the Battle of Monte Cassino. After the war, he lived in the Great Britain, first working in the fishing industry and then in the merchant navy. In 1959, during his visit to Poland, he was the subject of interest of the civil intelligence of the 
Janina (born on 23 XI 1919) 22.

At the beginning of World War I, as an artillery warrant officer, he was called up to the Russian army. As a result, he could not defend his diploma project at the university. Initially, he served in the fortress in Brest (formerly Brest-Litovsk), where he arrived on 22 July 1914 as a junior officer of the 14th Fortress Artillery Company at the 6th fort. On 29 November, he was appointed commander of the 6th battery of the 3rd Siege Artillery Regiment and sent to the front. Among others, he fought near Ciechanów, Pułtusk, Przasnysz, Gródek and Wyszków. Still in 1914, he was awarded with the Cross of St. Stanislaus 3rd class, and in April of the following year with the Order of St. Anna 4th class. On 15 July 1915, he was promoted to the rank of second lieutenant. He served in the 3rd Siege Artillery Regiment, which was reformed in November 1916 and incorporated as the 1st Brigade Division (pl. dywizjon)

Polish People's Republic (Department I of the Ministry of Interior). After: Archives of the Hoover Institution, Independent Historical Office of the Command of the Polish Armed Forces in the Soviet Union - Documentation Office of the Polish Army in the East. Documents of Władysław Anders. Reports, ref. no. 800/1/0/-/47, https://www.zapisyterroru. $\mathrm{pl} /$ dlibra/publication/6451/edition/6418/content?navq=aHR0cDovL3d3dy56YXBpc3l0ZXJyb3J1LnBsL2RsaWJyYS9yZXN1bHRzP2FjdGlvbj1BZHZhbmNlZFNlYXJjaEFjdG lvbiZ0eXBlPS0zJnNlYXJjaF9hdHRpZDE9Njcmc2VhcmNoX3ZhbHVlMT1EZXBvcnRh Y2phXC9aZXMlQzUlODJhbmllJnA9MA\&navref=NHlzOzR4diAzeTY7M3hlIDR6Nzs0 eWE (5.05.2020); IPN Ka, 04/2247, Note of the Inspector of the Department I of the Provincial Headquarters of the Civic Militia [hereinafter: KW MO] in Katowice, Lieutenant Stanisław Kubat dated 4 V 1959 and 29 X 1959, sheet 4-6; ibidem, Official note of Second Lieutenant Franciszek Bilski, Senior Clerk of the Foreigners Registration Section of KW MO in Katowice, dated 10 II 1959, sheet 15; Billion Graves, https://billiongraves. pl/grave/Leonard-Szutkowski/2007092 (5.05.2020); ibidem, https://billiongraves.pl/ social-security/LEONARD-SZUTKOWSKI/6355800 (5.05.2020); United States Social Security Death Index (SSDI), https://www.myheritage.pl/research/collection-10002/indeks-zgonow-w-usa-wg-ubezpieczenia-spo\%C5\%82ecznego-ssdi?itemId=6300711-\&ac tion=showRecord\&recordTitle=Leonard+Szutkowski (5.05.2020).

22 Janina Bień (née Szutkowska) (23 XI 1919 - 27 II 2015) - graduate of the Higher School of Economics in Katowice, she worked for many years in the economic services of coal mining in the Zabrze Association of the Coal Industry in Zabrze. Vide: DAWO, fond 46, description 7, case 2769, Certificate of birth and baptism Issued on the basis of baptismal register on 31 XII 1925 in Kobryn, sheet II/12; Obituary of Janina Bien, "Gazeta Wyborcza” Katowice, http://nekrologi.wyborcza.pl/0,11,,312196,Janina-Bie\%C5\%84nekrolog.html, date of issue 4 III 2015 (5.05.2020). 
into the 7th Heavy Artillery Brigade. In 1916, he fought at Pastavy, Baranavichy, Smarhon', Skrobów and Kreva. He was appointed junior officer of the 2nd Battery of the First Division of the 7th Brigade. On 15 April, he became a lieutenant. He was honored with the Order of St. Anna 3rd class with Swords and the Cross of St. Stanislaus 2nd class with Swords. His division was reformed and renamed as the 2nd Heavy Field Artillery. Szutkowski was promoted to the senior officer of the 2nd Battery of the Division. For his subsequent battles, he was also awarded with the Order of St. Anna 2nd class. Under his orders, among others, the later general Stanisław Tatar served ${ }^{23}$. Already after the February 1917 Revolution, he received the Cross of St. George 4th class with a laurel leaf. In August 1917, he was evacuated, and already in September, he became a battery commander in the 1st reserve artillery division in Serpukhov. After the Bolshevik Coup, he remained in his position. He served in the Russian army until 25 June 1918, when he was demobilized. He reached the rank of staff captain (appointed on 15 April 1917) ${ }^{24}$. In the Polish Army, he was verified in the rank of reserve lieutenant ${ }^{25}$.

In 1918, he became a representative of the Diplomatic Agency of the Regency Council of the Kingdom of Poland for the Moscow Governorate based in Serpukhov. He became a member of the Board of the Association of Polish Military Men. This organization aimed to associate all Poles, soldiers serving in the units stationed in Serpukhov - both privates and officers. The idea was to support them during the October Revolution, help them to get into the country, and make it easier to join Polish units created at the time, particularly to the First Corps of Gen. Józef Dowbor-Muśnicki in Babruysk (he took care of equipping the soldiers going there with money and ensuring them free travel). Szutkowski was also the president of the County Council of Exiles, president

23 Z. S. Siemaszko, Działalność generała Tatara (1943-1949), Lublin 2004, p. 15.

24 DAWO, fond 46, description 7, case 2769, Official declaration (after 14 II 1920), sheet 3; ibidem, Summary of information about the candidate of 30 III 1920, sheet I/6v; ibidem, Curriculum vitae of L. Szutkowski of 3 IV 1920, sheet II/3; ibidem, CV of 1 II 1921, sheet II/5; ibidem, Certificate of 20 II 1935 on the military service of eng. L. Szutkowski, reserve lieutenant, for the purpose of receiving pension, sheet II/35; Notarial confirmation of Stanisław Tatar of 20 II 1935, sheet II/ 35-36; CAW, KAPiO, Leonard... Rejected, CV...

25 Ibidem, Leonard Szutkowski, ref. no. 4345, Qualification list; DAWO, fond 46, description 7, case 2769, Copy of the officer's service book of 23 IX 1931, sheet II/42. 
of the Polish Association of Consumers, member of the Board of the Polish House in Serpukhov, and the Polish Committee president in Serpukhov. On 25 May 1918, he was released from the army due to demobilization. He renounced his Russian servitude and was therefore removed from the officers' register. Aleksander Lednicki, a representative of the Regency Council in Poland, holding office in Moscow, appointed him a representative for the Moscow Governorate based in Serpukhov. Szutkowski organized the departure of Poles to Poland. On 6 November, the Bolshevik secret police Cheka searched his place and took his documents and personal belongings. On 10 January 1919, he was imprisoned by the Bolsheviks as a hostage of Poles. Thanks to one of his former subordinates' help, he was released, and the surveillance was applied. Shortly afterward, he escaped and returned to reborn Poland on 26 February $1919^{26}$.

Initially, he moved into his father's estate in Khmelyshche. Looking for a job, he went to Brest and stayed overnight in the local Warsaw Hotel. On 14 February 1920, he was delegated by the Head of the Brest Branch of the Civil Administration of the Eastern Lands to a technical clerk position. He performed the duties of a county engineer at the Technical Section of the County Office in Kobryn. When applying for this position, he indicated his experience gained during internships in the Dąbrowa Basin mines: "Paris" and "Flora"27.

When assuming the duties of a county engineer, he took an oath in BrestLitovsk:

"By taking up the position of an official in the Civil Administration of the Eastern Lands, I solemnly promise to serve the Polish Homeland and Nation faithfully and with all my soul, to always act for the benefit of the Polish State and the public good according to the best of my understanding, to strictly observe legal regulations and governmental decisions concerning the matters

${ }^{26}$ Ibidem, Official declaration..., sheet I/3; ibidem, Summary of information..., sheet I/6v; ibidem, CV of 1 II 1921, sheet II/5; Statement of M. Pęski of 8 V 1933, sheet II/ 33; CAW, KAPiO, Szutkowski Leonard..., CV...

27 DAWO, fond 46, description 7, case 2769, Copy of the letter of 14 II 1920 from the Head of the Brest Region to L. Szutkowski, sheet I/5; ibidem Letter of 21 V 1920 from the Civil Administration of the Eastern Lands to Leonard Szutkowski, sheet I/14; ibidem, Application of L. Szutkowski to the technical inspector of Brest Region from January 1920, sheet II/2; ibidem, Letter of 17 XI 1927 from the Polesia Voivode to the Ministry of Public Works in Warsaw, sheet 1/180. 
entrusted to me, to keep the official secrecy, to fulfill the duties of my Office diligently and conscientiously, and to thoroughly follow the orders of my superiors. I hereby declare this oath with my honor and my signature"28.

Today, it is difficult to assess the effect of Leopold Szutkowski's activities in Polesia at that time. The most important issue was rebuilding the war damage. The roads and bridges were in terrible condition. Building materials necessary for their reconstruction and also for the reconstruction of buildings were generally lacking. The locals were stealing the existing materials, including elements of narrow-gauge railway infrastructure. According to Wojciech Śleszyński, there were not enough competent officials, and the administration's activities were characterized by organizational chaos ${ }^{29}$. Piotr Cichoracki points out that the work of the administration in Polesia was evaluated poorly ${ }^{30}$. Szutkowski could thus be one of the few competent persons in his position. In a study on economic life in the Borderlands, published during the interwar period, Wiktor Ormicki described the Włodawa-Kobryn-Slonim road condition as excellent. Still, most of the roads in Polesia required considerable investments ${ }^{31}$. In 1923, Voivode Stanisław Downarowicz, when speaking about the need for investment, identified Polesia as the country's poorest part ${ }^{32}$. All the Eastern Lands' Civil Administration were negatively perceived by the Belarusian community, which treated the Polish government as temporary ${ }^{33}$.

In the summer of 1920, the Red Army began the offensive. On 24 July 1920, together with the Technical Department of the Kobryn Starosty workers, Szutkowski was assigned to the civil technical forces of the Head Office of

${ }^{28}$ Ibidem, Oath taken by L. Szutkowski of 30 III 1920, sheet I/11.

${ }^{29}$ W. Śleszyński, Województwo poleskie, Kraków 2014, pp. 25-28.

30 P. Cichoracki, Województwo poleskie 1921-1939. Z dziejów politycznych, Łomianki 2014, p. 80.

31 W. Ormicki, Życie gospodarcze Kresów Wschodnich Rzeczypospolitej Polskiej, Kraków 1929, p. 77, 189. This condition can be seen in many photographs from that times, vide: A. Trapszyc, Polesie w fotografii z lat 20. i 30. XX wieku. Kontrasty, głębie powiększenia, Toruń 2019, pp. 44-131.

32 W. Śleszyński, 1923 II 28, Brześć nad Bugiem. - Program wojewody poleskiego Stanisława Downarowicza o zadaniach i pracach państwowych na Polesiu skierowanych do Wydziału Narodowościowego Ministerstwa Spraw Wewnętrznych, [in:] Polesie w polityce rządów II Rzeczypospolitej, Białystok-Kraków 2009, p. 32.

33 W. Śleszyński, Województwo poleskie... 
Engineering and Sappers of the Polesia Group under the command of General Władysław Sikorski. He organized sapper as well as road- and bridge-building units. On 9 August, the Technical Department, together with the Polesia Group, became part of the fourth Polish Army and was named the Technical Department of Roads and Bridges at the fourth Army. As part of this team, Szutkowski worked on repairs of roads, bridges, and river crossings, including the Wieprz and Vistula rivers. The engineers followed the army and carried out roadworks. Szutkowski was the head of the 2nd Road-Building Unit. His work was of vital importance during the retreat of the Fourth Army ${ }^{34}$. After a breakthrough in the Battle of Warsaw, as the front line moved eastwards, he found himself again in Brest. On 1 September, he was assigned to the disposal of Captain Kruszelnicki, Head of the Fortification Board of the Brest-Litovsk fortified camp, where he worked on the fortress's fortification. On 29 September, he wrote:

"I took up the works within the fortress and at the same time obtained permission from the Command of the 4th Army for carrying out road works in Kobryn County and partly in Brest County. When the 4th Army Staff moved forward, I had the following options: either 1) to move to Kobryn County, if the civil authorities demand it, or 2) take up fortification and road works on a larger scale and reorganize my unit into a fortification group. And on 1 October, as long as I am recommended, I can leave for Kobryn County. The Technical Department of the Kobryn Starosty is currently with me"35.

On 1 October 1920, after defeating the Bolsheviks, the Administration of the Frontline and Stage Territories appointed him as a technical clerk and county engineer in Kobryn. On 13 October, he was dismissed from the military service along with the entire personnel because the head of the Technical Department of Public Works reappointed him as an engineer of Kobryn

${ }^{34}$ DAWO, fond 46, description 7, case 2769, Letter of 29 V 1921 from L. Szutkowski to the Liquidation Committee of the former Civil Administration of the Eastern Lands, sheet I/17; ibidem, Letter of 24 VII 1920 from the Polesia Group command to the Kobryn Starosty, sheet I/24; ibidem, Report by Leonard Szutkowski, Head of the Technical Department of Roads and Bridges at the fourth Army, dated 29 IX 1920, sheet I/19; ibidem, CV of 1 II 1921, sheet II/5; ibidem, Report by L. Szutkowski for the Polesia Regional Directorate of Public Works in Brest-on-the-Bug dated 31 III 1923, sheet I/73.

35 Ibidem, Report by Leonard Szutkowski, Head of the Technical Department of Roads and Bridges at the fourth Army, dated 29 IX 1920, sheet I/19. 
County. From 23 September 1921, he was a road engineer of Kobryn County in the Regional Directorate of Public Works of Polesia Voivodeship ${ }^{36}$.

He was thinking about completing his university studies - he had no diploma and still needed to pass several exams. That is why, in March 1923, he informed the Polesia Regional Directorate of Public Works in Brest-on-theBug that he had enrolled at the Academy of Mining in Cracow and that all the courses he used to attend at the Warsaw University of Technology had been deemed passed. He asked to be granted a two-month leave to finish his studies ${ }^{37}$.

The Polesia Voivode, who agreed to the leave, wrote in his justification:

"Szutkowski is one of the best engineers and an outstanding administrator. If Mr. Szutkowski was denied his leave, he would resign from work what would adversely affect the course of affairs in the county"38.

He received leave from 5 May to 5 July that year. He used only one month and asked for the possibility of using the rest in autumn. He took another leave in $1924^{39}$.

In 1924-1925, he completed his education at the Faculty of Mining of the Mining Academy in Cracow. On 28 May 1924, he submitted his diploma thesis in the field of mining with prof. Henryk Czeczott. He completed an entire programme of studies at this faculty. On 23 March 1925, he passed the oral diploma examination with a result dobry (good). On 4 May that year, the Faculty of Mining Council awarded him the degree of mining engineer ${ }^{40}$.

36 Ibidem, CV of 1 II 1921, sheet II/5; ibidem, Letter of 15 X 1920 from the Head of the Technical Department of Public Works to the Kobryn Starost, sheet I/23; ibidem, Certificate of the Head of the Fortification Board of the Brest-Litovsk Fortified Camp of 13 X 1920, sheet I/25; ibidem, Letter of 28 X 1921 from Walery Roman, the Polesia Voivode, to L. Szutkowski, sheet I/60.

37 Ibidem, Report by L. Szutkowski for the Polesia Regional Directorate of Public Works in Brest-on-the-Bug dated 31 III 1923, sheet I/73.

38 Ibidem, Opinion of the Polesia Voivode of 5 IV 1923, sheet /74.

39 Ibidem, Letter of 7 V 1923 from the Polesia Voivode to L. Szutkowski, sheet I/76; ibidem, Letter of 6 VI 1923 from L. Szutkowski to the Polesia Regional Directorate of Public Works in Brest-on-the-Bug, sheet I/77; ibidem, Letter of 18 IV 1924 from the Ministry of Public Affairs in Warsaw to the Voivode in Brest-on-the-Bug, sheet I/106.

40 Ibidem, Certificate of prof. H. Czeczott dated 28 V 1924, sheet II/28; ibidem, Certificate of Dean of the Faculty of Mining of the Mining Academy in Cracow dated 30 III 1925, sheet II/29; Ibidem, Letter of 17 XI 1927 from the Polesia Voivode to the Ministry 
In October 1925, he was the manager of the State Administration of Roads in Kobryn. Since 15 June 1927, he has been undergoing 6-week exercises in the 30th Field Artillery Regiment in Włodawa and 9th Field Artillery Regiment ${ }^{41}$.

At that time, the exploitation of natural resources in Volhynia was being organized. Granite quarries in Klesiv and Tomashhorod were already operating. There were plans to open chalk and brown coal mines; hard coal deposits were looked for as well. Basalt quarries in Janowa Dolina were established ${ }^{42}$.

Leonard Szutkowski was sent to Janowa Dolina by a decision of Moraczewski, the Minister of Public Works ${ }^{43}$. On 14 July 1928, by way of confidential correspondence, the Minister informed the Voivodeship Office in Lutsk that there is an engineer-miner working in the Polesia Voivodeship, who can be transferred in connection with the planned expansion of the quarries in Volhynia. A week later, Szutkowski was already going to Janowa Dolina to see the quarries ${ }^{44}$. However, the Polesia Voivode did not want to agree to change the engineer's place of work. In a letter to the Ministry, we read:

"Eng. L. Szutkowski has not been working in mining for a long time now [...]. Eng. L. Szutkowski is almost the only engineer in Polesia who gives a liv-

of Public Works in Warsaw, sheet 1/180; ibidem, Copy of the register No. 1333 of $23 \mathrm{~V}$ 1925, sheet II/30; Diploma of L. Szutkowski confirming his title mining engineer, sheet II/31.

${ }^{41}$ Ibidem, Letters of 26 X 1925 and 14 VI 1927 from L. Szutkowski to the Polesia Regional Directorate of Public Works, sheet I/165, sheet I/176; ibidem, Letter of 24 VI 1927 from J. Sarnecki, Kobryn Starost, to the Voivodeship Office in Brest-on-the-Bug, sheet I/178. Ibidem, Report by Leonard Szutkowski for the Regional Directorate of Public Works dated 14 VI 1927 sheet I/176; CAW, KAPIO, Szutkowski Leonard, AP 4345, Qualification card.

42 Kopaliny na Wołyniu, "Kurier Wołyński" 1938, no. 19, p. 4; S. Małkowski, Z geologii Wotynia, "Rocznik Wołyński" 1931, vol. 2, pp. 386-401.

${ }_{43}$ DAWO, fond 46, description 7, case 2769, Letter of 19 I 1929 from Franciszek Księżopolski, Director of the Regional Directorate of Public Works of the Volhynian Voivodeship Office in Lutsk, to the Presidential Department of the Volhynian Voivodeship Office, sheet I/202.

${ }^{44}$ Ibidem, Letter of 14 VII 1928 from J. Moraczewski, Minister of Public Works, to the Voivodeship Office in Lutsk, sheet I/195; ibidem, Letter of 21 VIII 1928 from the Polesia Voivode to engineer L. Szutkowski, Manager of the State Administration of Roads in Kobryn, sheet I/198. 
ing example of a single-track road economy, [...] as he was born in Kobryn and knows the local conditions perfectly well and is an invaluable road engineer. In the current conditions, where there is a complete lack of candidates for road engineers and especially experienced specialists, L. Szutkowski's departure would result in long-term dereliction of road-related matters in Kobryn County. [...] Managing quarries in Volhynia should not, in any case, be detrimental to the organization of road administration in Polesia"45.

In response, the Ministry stated that "no other suitable manager of the quarry's construction and operation was found", and on 24 August that year, it issued a decision to assign Szutkowski to Janowa Dolina "to commence the construction and operation of the quarry". Szutkowski had to leave immediately. His secondment was to be turned into relocation as soon as another person was hired in Kobryn (soon, engineer Henryk Rudnicki took over his responsibilities) ${ }^{46}$. Simultaneously, in connection with mechanical equipment installation in the quarry, he was included in the delegation to Belgium, Switzerland, and Germany. The delegation team was to visit local quarries which had state-of-the-art mechanical equipment at their disposal ${ }^{47}$. He officially started working in the quarry on 1 September 1928 by a decree of the Ministry of Public Works ${ }^{48}$.

The basalt quarry in Janowa Dolina was just beginning its exploitation. In 1925, detailed geological surveys were carried out, and the extraction started in October 1928. In 1929, with the production of 90,000 tonnes and employment of 1,000 workers, the quarry met the road-building industry's needs in Volhynia. It became a strong competitor for private companies, especially the quarries in Berestovets. The development was 'bold' and 'on a large scale'. The material in the form of cobblestone and irregular cobblestone was sent to the

45 Ibidem, Letter of 20 VII 1928 from Wincenty Tyszko, Polesia Vice-Voivode, to the Ministry of Public Works in Warsaw, sheet I/199.

46 Ibidem, Letters of 24 VIII 1928 and 5 IX 1928 from K. Górski, Undersecretary of State of the General Department of the Ministry of Public Affairs in Warsaw, to the Polesia Voivode, sheet I/196 and I/207.

47 Ibidem, Letter of 27 VIII 1928 from J. Moraczewski, Minister of Public Works, to the Polesia Voivode in Brest-on-the-Bug, sheet I/197; A. Czuchryta, Gospodarka województwa wotyńskiego 1921-1939, Lublin 2016, p. 182.

48 CAW, KAPiO, Szutkowski Leonard... Rejected, CV... 
Silesian and Pomeranian Voivodeships ${ }^{49}$. Janowa Dolina quickly became the largest quarry in Volhynia. The most extensive deposits in Poland were exploited there. One of the first major problems was to create a suitable infrastructure. The Horyn River, on which Janowa Dolina lies, did not meet the conditions necessary for proper transport. There was no railway line, so an $18-\mathrm{km}$ long siding was built. The timber was harvested from forests cleared for the quarry's needs, and it was used for the construction of numerous utility buildings, houses for administration, and workers' barracks.

In many cases, the unemployed people were offered jobs, which was supposed to improve local residents' living standard. However, mainly Poles came to work in Janowa Dolina, not Ukrainians who constituted the majority in Volhynia. On the premises of the quarry, there were: a power plant, police station, medical clinic, school, kindergarten, voluntary fire brigade, sports club 'Strzelec', playing field, orchestra, canteen, and kiosks; preparations aimed at the construction of a parish church were also underway. To this end, in 1937, the Association of Architects of the Republic of Poland (branch in Lutsk) announced a special contest for the building project. Wooden houses for workers' families created a picturesque settlement. Engineer Kazimierz Przybyłowski (died on 11 March 1938) was the construction manager for the so-called workers' colony ${ }^{50}$. In "Wołyńskie Wiadomości Techniczne" (Volhynian Technical News) we read:

"As far as the construction of workers' houses in Volhynia and Poland is concerned, Janowa Dolina is a true pioneer. This workplace could be called a housing laboratory. So far, the experiments have been aimed at providing accommodation to white-collar workers and the best, i.e. the most qualified staff and best-paid workers. Besides, these houses were built according to the company town model; they were the company's property and were to be leased

49 Państw. Kamieniołomy bazaltu na Wołyniu, "Wołyńskie Wiadomości Techniczne" 1929, no. 12, p. 7; M. Orłowicz, Ilustrowany przewodnik po Wołyniu, Łuck 1929, pp. 219-221; Państwowe Kamieniołomy w Janowej Dolinie (1928), [in:] Rocznik Polskiego Przemysłu i Handlu 1932, ed. T. Szober, Warszawa, no. 1129.

50 A. Czuchryta, Gospodarka województwa..., pp. 180-183; B. Soboń, op. cit., p. 13. Vide: Badania geologiczne na Polesiu i Wołyniu, „Wołyńskie Wiadomości Techniczne” 1928, no. 7, p. 7; 84 konkurs S.A.R.P. (oddział $w$ Łucku) na projekt kościoła parafialnego $w$ Janowej Dolinie, "Wołyńskie Wiadomości Techniczne" 1937, no. 11, pp. 1-5; Z żałobnej karty, "Wołyńskie Wiadomości Techniczne” 1938, no. 3, p. 13. 
to workers without the prospect of ownership transfer. Recently, with the help of the Labor Fund, Janowa Dolina has started further experiments to develop a type of workers' house which could be, without special effort, depreciated paid off by a worker who receives average earnings" ${ }^{\prime \prime}$.

In 1939, there were plans to build the so-called "stone channel" and make the Horyn River passable. It would enable river transport of the extracted material: granite from Klesiv and basalt from Janowa Dolina ${ }^{52}$.

Szutkowski quickly became known as a talented, energetic, and highly initiative-oriented professional and, at the same time, as a conscientious, hardworking, and diligent official worthy of promotions ${ }^{53}$. On 24 June 1929, at the meeting of the Council of Ministers, a resolution was adopted to exempt him from the obligation to take the practical examination for candidates for the first category position in the state technical service in the department of the Ministry of Public Works. As a result of administrative and economic reforms, the Ministry of Transport started to manage the quarries. Consequently, on 3 July that year, Szutkowski was appointed the construction counselor in the 6 th grade of service ${ }^{54}$. In 1934, after the publication of the regulation of the Council of Ministers on establishing a plan of posts in governmental bodies, offices, facilities, and state institutions, he was appointed by Minister Michał Butkiewicz as the Manager of State Quarries in Janowa Dolina, classified in the seventh salary group, and from 1 May in the sixth salary group ${ }^{55}$. In 1935 , as part of a skills improvement course for engineers, he conducted 4-hour classes at the Lviv Polytechnic on the subject: "Equipment and management of

51 S. Boryssowicz, Mieszkania robotnicze, jako problem gospodarczy, "Wołyńskie Wiadomości Techniczne” 1939, no. 4, pp. 3-5.

52 J. Kiersnowski, Kanał kamienny, "Wołyńskie Wiadomości Techniczne” 1939, no. 4, pp. 1-2.

53 DAWO, fond 46, description 7, case 2769, Letter of 29 I 1929 from Franciszek Księżopolski, Director of the Regional Directorate of Public Works of the Volhynian Voivodeship Office in Lutsk, to the Presidential Department of the Volhynian Voivodeship Office, sheet I/203.

54 Ibidem, Letter of 3 VII 1929 from K. Górski, Undersecretary of State in the General Department of the Ministry of Public Works, to the Volhynian Voivode in Lutsk, sheet $\mathrm{I} / 221$.

55 Ibidem, Letters of 20 I 1934 and 26 IV 1834 from the Minister Michał Butkiewicz to L. Szutkowski, sheet I/240-241; ibidem, Letter of 4 V 1934 from Mikołaj Godlewski, Volhynian Vice-Voivode, to L. Szutkowski, sheet I/243. 
quarries" ${ }^{\prime 56}$. At the beginning of November of the same year, he was instructed to delegate to Sweden together with the manager eng. Stanisław Bobrowski to analyze the operation of local quarries and learn about the equipment used there ${ }^{57}$. He left on 8 November and returned on 20 November $^{58}$. The result of this trip was the first Szutkowski's lecture delivered for the Volhynian Association of Technicians, of which he was a member ${ }^{59}$, and then two articles published in "Wołyńskie Wiadomości Techniczne" on roads and stone industry in Sweden ${ }^{60}$.

Szutkowski could be proud of the business he managed. The press has written about the rapid expansion of the workers' settlement in Janowa Dolina, the construction of new streets, modern workers' houses, schools with a playground, waterworks, and central heating ${ }^{61}$. In 1935, as many as 2,500 people were already employed there, daily production reached 1,500 tonnes of road materials. Deputy Minister Julian Piasecki visited the quarry ${ }^{62}$.

56 Ibidem, Skills improvement training programme for engineers covering the production of building materials, sheet I/253; ibidem, Copy of the letter of 16 I 1935 from prof. Antoni Wereszczyński from the Lviv Polytechnic to the Ministry of Religious Affairs and Public Education, sheet I/252; ibidem, Consent of the Head of Transport and Construction Department of the Volhynian Voivodeship Office dated 13 II 1935 to the participation of L. Szutkowski in the course, sheet I/251; Letter of 11 V 1935 from the Volhynian Vice-Voivode to L. Szutkowski, sheet I/258.

57 Ibidem, Copy of a telephonogram of the Ministry of Transport dated 2 XI 1935, sheet I/260.

58 Ibidem, Memo of the Head of Transport and Construction Department of the Volhynian Voivodeship Office dated 22 XI 1935, sheet I/263.

${ }_{59}$ Protokół XIX Zwyczajnego Walnego Zgromadzenia członków Wołyńskiego Stowarzyszenia Techników w Eucku, odbytego dnia 26 kwietnia 1936 r., "Wołyńskie Wiadomości Techniczne” 1936, no. 5, pp. 10-11; Wykaz członków Wołyńskiego Stowarzyszenia Techników w Łucku na 1 stycznia 1935 r., "Wołyńskie Wiadomości Techniczne" 1935, no. 1-2-3, p. 12; Wykaz członków Wołyńskiego Stowarzyszenia Techników w Eucku na 1 stycznia 1936 r., "Wołyńskie Wiadomości Techniczne" 1936, no. 1, p. 12.

${ }^{60}$ L. Szutkowski, Drogi i przemysł kamieniarski w Szwecji, "Wołyńskie Wiadomości Techniczne” 1936, no. 1, pp. 1-4; L. Szutkowski, Drogi i przemysł kamieniarski w Szwecji, "Wołyńskie Wiadomości Techniczne" 1936, no. 2, pp. 1-4.

61 Rozrost Janowej Doliny, “Życie Katolickie” 1935, no. 23, p. 363.

62 Z pobytu na Wołyniu p. Wiceministra J. Piaseckiego, "Wołyńskie Wiadomości Techniczne" 1935 , no. 7 , p. 8. 
The modernity of Janowa Dolina had a substantial social impact. In the light of the growing activity of the Organization of Ukrainian Nationalists, the quarries were supposed to be an excellent example of cooperation between Poles and Ukrainians. However, according to Czesław Piotrowski's findings, Poles were mainly employed and made up $90 \%$ of the staff ${ }^{63}$.

Shaping patriotic attitudes was an important aspect in the company. Here, we should evoke two specific events. In 1935, the quarry workers decided to donate 2 thousand tonnes of basalt to construct the Józef Piłsudski monument-mausoleum. The monument was to be a symbol of the feelings of the Polish nation. In 1938, in agreement with the Main Committee for Commemorating the Memory of Marshal Józef Piłsudski in Warsaw and the Chortoryisk Municipality Office, the quarry management delivered boulders, each $3 \mathrm{~m}$ high, which stood on concrete foundations in the place where Polish Legions fought in Kostiuchnówka ${ }^{64}$.

In the company run by Szutkowski, block paving and stonework courses, which enjoyed high interest, were organized by the Society for the Promotion of Vocational Education in Volhynia. In 1935, only 30 people were selected out of 150 applicants for a three-month course. A year later, the Labor Fund, in consultation with the quarry management, organized a six-month course. Its participants were young people from the Youth Labor Corps (pl. Junackie Hufce Pracy). It was consistent with the nationwide expansion of the "junaks" youth movement. Unfortunately, the course had to be shortened to 2 months, because the junaks were called for the so-called winter mobilization (from November to April, skill-improvement trainings were organized for poorly educated, often illiterate or semi-illiterate, youth) ${ }^{65}$.

63 T. Snyder, Tajna wojna. Henryk Józewski i polsko-sowiecka rozgrywka o Ukrainę, Kraków 2008, pp. 208-210; C. Piotrowski, Zniszczone i zapomniane osiedla polskie oraz kościoty na Wołyniu, Warszawa 2002, p. 87.

${ }^{64}$ Pomnik z bazaltu dla Marszalka Piłsudskiego, „Życie Katolickie” 1935, no. 23, p. 362; Uporządkowanie pobojowisk legionowych w Kostiuchnówce, "Wołyńskie Wiadomości Techniczne" 1938, no. 6, p. 11.

65 B. Maniecki, Potrzeby budownictwa drogowego, "Wołyńskie Wiadomości Techniczne" 1937, no. 6, pp. 9-10. 
At the end of 1937, the Minister of Industry and Trade Antoni Roman appointed Szutkowski as juror of the Mining Board (pl. Kolegium Górnicze) ${ }^{66}$. From 1 April 1938, he received a higher salary. Juliusz Ulrych, the Minister of Transport, granted him a basic salary classified to the 5 th group ${ }^{67}$. Szutkowski was also a member of the County Department in Kostopil and Provincial Council in Lutsk and the head of the Kostopil District (pl. obwód kostopolski) of the Camp of National Unity ${ }^{68}$. In addition to Szutkowski, the Board of the Kostopil District was also composed of: Lucjan Lenczowski, Jan Hermaszewski, and Bogdan Domański69. Szutkowski was also the President of all social organizations in Janowa Dolina, including the Association of Social Organizations and Voluntary Fire Brigades in Janowa Dolina ${ }^{70}$. In 1935, he participated in various patriotic celebrations, such as the opening of the first rally of the Volhynian Scouts' Division (pl. Wotyńska Choragiew Harcerzy) on the occasion of the 20th anniversary of the Volhynian Scouting ${ }^{71}$.

On 24-25 September 1937, the quarry in Janowa Dolina hosted the 3rd Annual Convention of Electrical Engineers of the Volhynian Voivodeship. The convention was attended by a representative of the Ministry of Industry and Trade, Counsellor E. Zieliński, and representatives of the Voivodeship Office in Lutsk. Szutkowski delivered a lecture about Janowa Dolina, provided an

66 DAWO, fond 46, description 7, case 2769, Decree of Antoni Roman, Minister of Industry and Trade, to engineer L. Szutkowski of 31 XII 1937, sheet I/280. Vide: J. Durka, Między praca a edukacją. Z życia Junackich Hufców Pracy na Kresach Wschodnich w II poł. lat 30. XX w., [in:] Oświata i nauka na Kresach Wschodnich w XIX i XX wieku, ed. J. Lusek, Bytom-Poznań 2018, pp. 196-197.

67 DAWO, fond 46, description 7, case 2769, Copy of the letter of 24 XII 1937 from Juliusz Ulrych, Minister of Transport, to L. Szutkowski, sheet I/279.

68 AAN, Camp of National Unity, ref. no. 37, Volhynian Area (Okręg Wołyń) - list of heads of districts [no date], sheet 22; ibidem, Volhynian Voivodeship, sheet 88; CAW, $\mathrm{KAPiO}$, Leonard... Rejected, CV...

69 DAWO, fond 440, description 1, case 1, Biuletyn Tygodniowy (Weekly Bulletin) no. 1 dated 20 VII 1938, sheet 126.

70 S. Łoza (ed.), Czy wiesz kto to jest?, Warszawa 1938, p. 307.

${ }^{71}$ CAW, KAPiO, Leonard... Rejected, CV...; Zlot harcerzy, "Życie Katolickie” 1935, no. 28, p. 443. 
opportunity to visit the facility, explained the details, and took part in the convention sessions ${ }^{72}$.

In 1939, Janowa Dolina was regarded as one of the models of a modern industrial center. It was essentially thanks to Director Leonard Szutkowski.

On 11 March 1930, he was awarded the Medal of the 10th Anniversary of Regaining Independence ${ }^{73}$. On 11 November 1935, the President of the Republic of Poland, Ignacy Mościcki, named Leonard Szutkowski one of the Knights of the Order of Polonia Restituta (5th Class) and awarded him the Knight's Cross of that Order ${ }^{74}$. On 1 June 1938, Szutkowski received a Brown Medal for Long Service. The ceremony took place on 15 August that year ${ }^{75}$. He was also awarded with the Commandant's Badge of Military Training, Commemorative Badge of the 44th Borderland Rifle Regiment, Commemorative Badge of the 45th Borderland Rifle Regiment, Commemorative Badge of Volhynian Scouts, Medal of the 15th Anniversary of Regaining Access to the Sea (awarded by the Maritime and Colonial League) as well as Silver Medal of Merit (awarded by the Main Association of Voluntary Fire Brigades) ${ }^{76}$.

After the Second World War outbreak, he did not take advantage of an opportunity offered to him and the government to flee to Romania. He said that he devoted so many years of his life to Janowa Dolina that leaving is not an option. He was wrong to believe that after many years, the Soviet terror had weakened. After the arrival of the Red Army, the mine was initially still under his leadership. He was supposed to introduce new managers. Control over the quarry, which employed 3 thousand people, was taken over by an NKVD officer Alexander Maksimovich Simonov. At the end of November, Leonard's son, a cadet of the Polish Army, returned home after being released from a prisoner-of-war camp in Częstochowa. On the night of 8-9 December 1939, the NKVD conducted a 3-4-hour search at the Szutkowski family's

72 Zjazd Zwiq̨zku Elektryków Wołyńskich w Janowej Dolinie, "Wołyńskie Wiadomości Techniczne" 1937, no. 10, p. 1.

73 DAWO, fond 46, description 7, case 2769, Letter of 31 III 1930 from the Head of the Presidential Department of the Volhynian Voivodeship Office to L. Szutkowski, sheet II/37.

${ }^{74}$ Ibidem, Copy of a statement of 2 XII 1935 r., sheet II/38.

75 Ibidem, Diploma for eng. L. Szutkowski signed by Aleksander Hauke-Nowak, Volhynian Voivode, dated 1 VI 1938, sheet II/39.

76 CAW, KAPiO, Leonard... Rejected, Application of 20 XII 1937. 
home. All the decorations, various valuable items (stamp and coin collection), and documents were taken. Director Szutkowski received an order to prepare for the departure; he was arrested. At the same time, many other Poles were arrested as well, including landowners and priests ${ }^{77}$. He was imprisoned in Kostopil, Rivne, and Kharkiv, where he was still seen in July 1941. Attempts to intervene in his defense were to no avail. Soon, his wife, son, and daughter moved to a clerical building, where several families lived. A Soviet commissar settled in the director's building. In February, there were arrests of reserve officers, foresters, and rangers. The family lived there until April 1940 (at that time, Szutkowski's son was working in the mine in the dispatch management), when the rest of the family members were deported. They were given only 2 hours to prepare for leaving. On 13 April, they were transported to Posiołek Limanówka in Kostanay Oblast, where they worked on a farm ${ }^{78}$.

After the Third Reich attacked the Soviet Union, Janowa Dolina found itself under German occupation. The Poles living there became a victim of the attack by the Ukrainian Insurgent Army. On the night of 22-23 April 1943 (Good Friday), more than 600 people died during the massacre ${ }^{79}$.

${ }^{77}$ L. Gadzina, Wspomnienia moje ze zderzenia z bolszewikami w dniu 17 września 1939 r., [in:] Moje zderzenie z bolszewikami we wrześniu 1939 roku, ed. K. Rowiński, London 1986, p. 48.

${ }^{78}$ Leonard Szutkowski's (son) recollection: Prześladowanie Polaków w Związku Sowieckim 15. Opowiada Leonard Szutkowski (Persecution of Poles in the Soviet Union 15. A story told by Leonard Szutkowski), Józef Piłsudski Institute of America, https:// www.youtube.com/watch?v=w3tnbw3fNDQ (5.05.2020); Irena Główka's recollections of 2013, http://wolyn.freehost.pl/wspomnienia/janowa_dolina-irena_glowka.html (5.05.2020).

${ }^{79}$ Relacja Eucji Arczyńskiej z d. Bogdanowicz, byłej mieszkanki osady Janowa Dolina (gm. I pow. Kostopol), datowana 25 lipca 1991 r., [in:] Ludobójstwo dokonane przez nacjonalistów ukrainskich na ludności polskiej Wotynia 1939-1945, vol. II, eds. W. Siemaszko, E. Siemaszko, Warszawa 2000, pp. 1128-1129; W. Siemaszko, E. Siemaszko, Ludobójstwo dokonane przez nacjonalistów ukraińskich na ludności polskiej Wotynia 1939-1945, vol. I, Warszawa 2000, pp. 232-237; G. Motyka, Ukraińska partyzantka 1942-1960. Działalność Organizacji Ukraińskich Nacjonalistów i Ukraińskiej Powstańczej Armii, Warszawa 2006, pp. 316-318; Movie „Powrót do Janowej Doliny” (Halina Kopacz’s recollection), Museum of the Second World War, 2019, https://www.youtube.com/watch?v=YI9rFsCNeMI (5.05.2020); vide: W. Filar, Wotyń 1939-1944. Eksterminacja czy walki polsko-ukraińskie. Studium historyczno-wojskowe zmagań na Wołyniu w obronie polskości, wary i godności ludzkiej, Torun 2003, p. 94; G. Hryciuk, Przemiany narodowościowe i ludnościowe w Galicji 
NKVD officers murdered Leonard Szutkowski. His name can be found on the Ukrainian Katyn List ${ }^{80}$. His grave is located at the Polish War Cemetery in Kiev-Bykivnia. In Poland, he was declared deceased by the County Court's decision in Zabrze only in $1951^{81}$.

\section{SUMMARY}

The article portrays Leonard Szutkowski, a Polish engineer born in Polesia who managed the quarry in Janowa Dolina in Volhynia. Szutkowski was a patriot, which he proved already during the First World War by engaging in Polish organizations' activities. He escaped the Bolsheviks from captivity and returned to reborn Poland. He took part in the Polish-Soviet War as an engineer working on roads and fortifications. After the war, he worked as a road engineer, completed his studies, and became a quarry manager in Janowa Dolina. The company was well-known for its modern solutions and was an undertaking the Second Polish Republic could be undoubtedly proud of. During the Second World War, Leonard Szutkowski was arrested and murdered by the NKVD. His name is present on the Ukrainian Katyń List. His grave is located at the Polish War Cemetery in Kiev-Bykivnia in Ukraine. This article was elaborated based on materials derived from the archive in Lutsk.

Wschodniej i na Wołyniu w latach 1931-1948, Torun 2005, p. 276; C. Piotrowski, Ziszczone i zapomniane osiedla..., p. 90; S. Jastrzębski, Kulisy martyrologii polskiej na Kresach Południowo-wschodnich Rzeczypospolitej, Katowice 2014, p. 107; D. Faszcza, Komenda Okregu AK „Wołyń” wobec eksterminacji ludności polskiej w 1943 r., "Niepodległość i Pamięć” 2013, no. 3-4, p. 81.

${ }^{80}$ Wykaz akt osobowych aresztowanych, wysłanych do NKWD ZSRR, [in:] Zeszyty Katyńskie nr 4: Listy katyńskiej ciag dalszy. Straceni na Ukrainie, ed. M. Tarczyński, Warszawa 1994, p. 95.

${ }^{81}$ AIPN Ka, 555/4621, Decision of the County Court of 18 VIII 1951, sheet 10. 


\section{BIBLIOGRAPHY}

\section{ARCHIVES}

The Archive of the Institute of National Remembrance in Katowice

04/2247; 555/4621

\section{Archives of the Hoover Institution}

Independent Historical Office of the Command of the Polish Armed Forces in the Soviet Union - Documentation Office of the Polish Army in the East. Documents of Władysław Anders. Reports, ref. no. 800/1/0/-/47

\section{The Archives of Modern Records in Warsaw}

Camp of National Unity, ref. no. 37,

Ministry of Supply in Warsaw, ref. no. 2/19/0/14.2/2689.

\section{Central Military Archives in Warsaw}

Collection of the Military Archival Commission:

- Szutkowski Wincenty, ref. no. VIII. 802.1300.26744,

Collection of Personal Records and Decorations:

- Szutkowski Julian, AP 16477,

- Szutkowski Julian, Committee of the Cross and the Medal of Independence 15-4377,

- Szutkowski Leonard, 21 VI 1938, Rejected,

- Szutkowski Leonard, AP 16476,

- Szutkowski Leonard, AP 4345.

\section{Derżawnyj Archiw Wołynśkoji Obłasti in Lutsk (Ukraine)}

fond 46 , description 7 , case 2769 ,

fond 440 , description 1 , case 1 .

\section{PUBLISHED DOCUMENTS}

W. Śleszyński, Polesie w polityce rządów II Rzeczypospolitej, Białystok-Kraków 2009.

Wykaz akt osobowych aresztowanych, wysłanych do NKWD ZSRR, [in:] Zeszyty Katyńskie nr 4: Listy katyńskiej ciąg dalszy. Straceni na Ukrainie, ed. M. Tarczyński, Warszawa 1994. 


\section{MEMORIES AND RELATIONS}

Gadzina L., Wspomnienia moje ze zderzenia z bolszewikami w dniu 17 września 1939 r., [in:] Moje zderzenie z bolszewikami we wrześniu 1939 roku, ed. K. Rowiński, London 1986.

Relacja Eucji Arczyńskiej z d. Bogdanowicz, byłej mieszkanki osady Janowa Dolina (gm. I pow. Kostopol), datowana 25 lipca 1991 r., [in:] Ludobójstwo dokonane przez nacjonalistów ukraińskich na ludności polskiej Wołynia 1939-1945, vol. II, eds. W. Siemaszko, E. Siemaszko, Warszawa 2000.

\section{PRESS}

"Dziennik Bydgoski" 1936

"Dziennik Poznański” 1936

"Gazeta Wyborcza" 2015

"Kurier Wołyński” 1938

"Lot i Obrona Przeciwlotniczo-Gazowa Polski" 1936

"Poleski Dziennik Wojewódzki” 1933

"Skrzydlata Polska" 1936

“Wołyńskie Wiadomości Techniczne” 1928, 1929, 1935-1938

“Życie Katolickie” 1935

\section{STUDIES}

Boryssowicz S., Mieszkania robotnicze, jako problem gospodarczy, "Wołyńskie Wiadomości Techniczne" 1939, no. 4.

Chlebowski B. (ed.)., Słownik Geograficzny Królestwa Polskiego i innych krajów stowiańskich, vol. XV, part 1, Warszawa 1900.

Cichoracki P., Województwo poleskie 1921-1939. Z dziejów politycznych, Łomianki 2014.

Czuchryta A., Gospodarka województwa wołyńskiego 1921-1939, Lublin 2016.

Durka J., Między praca a edukacja. Z życia Junackich Hufców Pracy na Kresach Wschodnich w II pot. lat 30. XX w., [in:] Oświata i nauka na Kresach Wschodnich w XIX i XX wieku, ed. J. Lusek, Bytom-Poznań 2018.

Epsztain T., Górzyński S. (eds.), Spis ziemian Rzeczypospolitej Polskiej w roku 1930: województwo poleskie, województwo wołyńskie, Warszawa 1996.

Faszcza D., Komenda Okręgu AK „Wołyń” wobec eksterminacji ludności polskiej w 1943 r., "Niepodległość i Pamięć" 2013.

Filar W., Wotyń 1939-1944. Eksterminacja czy walki polsko-ukraińskie. Studium historyczno-wojskowe zmagań na Wotyniu w obronie polskości, wary i godności ludzkiej, Torun 2003.

Hryciuk G., Przemiany narodowościowe i ludnościowe w Galicji Wschodniej i na Wotyniu w latach 1931-1948, Toruń 2005. 
Jastrzębski S., Kulisy martyrologii polskiej na Kresach Południowo-wschodnich Rzeczypospolitej, Katowice 2014.

Kiersnowski J., Kanał kamienny, "Wołyńskie Wiadomości Techniczne” 1939, no. 4.

Kozłowski W., Artyleria polskich formacji wojskowych podczas I wojny światowej, Łódź 1993.

Małkowski S., Z geologii Wołynia, "Rocznik Wołyński” 1931, vol. 2.

Maniecki B., Potrzeby budownictwa drogowego, "Wołyńskie Wiadomości Techniczne" 1937, no. 6.

Mędrzecki W., Inteligencja polska na Wotyniu w okresie międzywojennym, Warszawa 2005.

Mędrzecki W., Kresowy kalejdoskop. Wędrówki przez ziemie wschodnie Drugiej Rzeczypospolitej 1918-1939, Kraków 2018.

Motyka G., Ukraińska partyzantka 1942-1960. Działalność Organizacji Ukraińskich Nacjonalistów i Ukraińskiej Powstańczej Armii, Warszawa 2006.

Orłowicz M., Ilustrowany przewodnik po Wołyniu, Łuck 1929.

Ormicki W., Życie gospodarcze Kresów Wschodnich Rzeczypospolitej Polskiej, Kraków 1929.

Piotrowski C., Zniszczone i zapomniane osiedla polskie oraz kościoły na Wołyniu, Warszawa 2002.

Rybak A., Smółka A., Wieża Eiffla nad Pinq.. Kresowe marzenia II RP, Wołowiec 2019.

Siemaszko W., Siemaszko E., Ludobójstwo dokonane przez nacjonalistów ukraińskich na ludności polskiej Wotynia 1939-1945, vol. I, Warszawa 2000.

Siemaszko Z.S., Działalność generała Tatara (1943-1949), Lublin 2004.

Śleszyński W., Województwo poleskie, Kraków 2014.

Snyder T., Tajna wojna. Henryk Józewski i polsko-sowiecka rozgrywka o Ukrainę, Kraków 2008.

Soboń B., Wołyński życiorys: wspomnienia i refleksje (wokó kopali bazaltu w Janowej Dolinie pow. Kostopol), Warszawa 1999.

Szober T. (ed.), Rocznik Polskiego Przemysłu i Handlu 1932, Warszawa, no. 1129.

Szutkowski L., Drogi i przemysł kamieniarski w Szwecji, "Wołyńskie Wiadomości Techniczne" 1936, no. 1.

Szutkowski L., Drogi i przemysł kamieniarski w Szwecji, "Wołyńskie Wiadomości Techniczne" 1936, no. 2.

Trapszyc A., Polesie w fotografii z lat 20. i 30. XX wieku. Kontrasty, głębie powiększenia, Toruń 2019.

\section{INTERNET}

Billion Graves, https://billiongraves.pl (5.05.2020).

Biogramy Ofiar Zbrodni Katyńskiej, http://ksiegicmentarne.muzeumkatynskie.pl/ wpis/7623 (21.05.2020). 
Chajewski D., Stanisław Nicieja: jestem jak płetwonurek szukajacy Atlantydy, https:// plus.gazetalubuska.pl/stanislaw-nicieja-jestem-jak-pletwonurek-szukajacyatlantydy/ar/c1-14661737 (5.05.2020).

Movie „Powrót do Janowej Doliny” (Halina Kopacz's recollection), Museum of the Second World War, 2019, https://www.youtube.com/watch?v=YI9rFsCNeMI (5.05.2020).

Glass A., Jan Tadeusz Staszek, https://www.ipsb.nina.gov.pl/a/biografia/jan-tadeusz-staszek (5.05.2020).

Irena Główka's recollections of 2013, http://wolyn.freehost.pl/wspomnienia/janowa_dolina-irena_glowka.html (5.05.2020).

Julian Szutkowski (ID: katyn.736), [in:] Genealogia potomków Sejmu Wielkiego, ed. M. J. Minakowski, http://www.sejm-wielki.pl/b/katyn.736 (21.05.2020).

Leonard Szutkowski's (son) recollection: Prześladowanie Polaków w Związku Sowieckim 15. Opowiada Leonard Szutkowski (Persecution of Poles in the Soviet Union 15. A story told by Leonard Szutkowski), Józef Piłsudski Institute of America, https://www.youtube.com/watch?v=w3tnbw3fNDQ (5.05.2020).

Mikulski Z., Wspaniaty rozwój Szkoty Szybowcowej na Sokolej Górze koło Krzemieńca, "Życie Krzemienieckie" 1934, no. 4, http://nawolyniu.pl/artykuly/sokolagora. $\operatorname{pdf}(5.05 .2020)$.

MyHeritage, https://www.myheritage.pl (5.05.2020).

Nekrologi warszawskie, http://www.nekrologi-baza.pl/zmarly/286574 (2.05.2020).

Sawik L., Kosmos Białorusa, trans. I. Kuprys, http://bkit.lt/kita.pl.html (5.05.2020).

Купала Янка, [in:] Электронная Энщыкляпэдыя, 2003-2020, http://slounik. org/120792.html (5.05.2020 r.). 